\title{
Chronic Pain Syndromes in Gynaecological Practice: Endometriosis and Fibromyalgia
}

\author{
Chronische Schmerzsyndrome in der gynäkologischen Praxis: \\ Endometriose und Fibromyalgiesyndrom
}

Author

Affiliation
F. Siedentopf

Klinik für Gynäkologie und Geburtshilfe, Martin-Luther-Krankenhaus, Berlin

\section{Key words \\ - Endometriosis \\ - fibromyalgia \\ - psychosomatics \\ Schlüsselwörter \\ - Endometriose \\ - Fibromyalgie \\ - Psychosomatik}

\section{Abstract \\ $\nabla$}

As gynaecologists frequently function as "general practitioners" for women, gynaecologists are frequently confronted with questions which initially appear to have only a tenuous connection to their field. Chronic pain syndromes represent a particular challenge, especially as pain syndromes are often associated with severe psychosocial stress for the affected woman. This article discusses some of the psychometric aspects of chronic pain in endometriosis and fibromyalgia together with practical therapeutic approaches.

\section{Zusammenfassung \\ $\nabla$}

In seiner Funktion als „Hausarzt“ der Frau wird der behandelnde Gynäkologe nicht selten mit Fragestellungen konfrontiert, die zunächst nur bedingt in sein originäres Fachgebiet zu gehören scheinen. Eine besondere Herausforderung in diesem Kontext können chronische Schmerzsyndrome sein, die eine ausgeprägte psychische Belastung für die betroffene Frau mit sich bringen können. In dem folgenden Beitrag soll auf die psychosomatischen Aspekte der chronischen Schmerzen bei Endometriose sowie beim Fibromyalgiesyndrom (FMS) eingegangen werden sowie praxisorientierte Handlungsansätze aufgezeigt werden.

$\begin{array}{ll}\text { received } & 9.10 .2012 \\ \text { revised } & 17.11 .2012 \\ \text { accepted } & 18.11 .2012\end{array}$

Bibliography

DOI http://dx.doi.org/

$10.1055 / \mathrm{s}-0032-1328064$

Geburtsh Frauenheilk 2012; 72:

1092-1098 @ Georg Thieme

Verlag KG Stuttgart · New York . ISSN 0016-5751

\section{Correspondence}

\section{Dr. Friederike Siedentopf}

Martin-Luther-Krankenhaus

Klinik für Gynäkologie und Geburtshilfe

Caspar-Theyß-Straße 27-31

14193 Berlin

friederike.siedentopf@gmx.de

\section{Introduction}

$\nabla$

The diagnostic criteria for persistent somatoform pain disorders (F 45.4) apply to many female patients with chronic pain; in patients with chronic pelvic pain the rate is around $60-80 \%$ [1]. The definition of chronic pain disorder according to the ICD 10 is as follows. "The predominant complaint is persistent, severe and distressing pain which cannot be fully explained by a physiological process or a physical disorder. It occurs in association with emotional conflict or psychosocial problems that are sufficient to allow the conclusion that they are the main causative influences. The result is usually a marked increase in support and attention, either personal or medical. Pain presumed to be of psychogenic origin occurring during the course of depressive disorders or schizophrenia should not be included here." [2]

Persistent pain syndrome occurs in patients of every social class and with every level of education. However it occurs more frequently in persons of a lower socio-economic status, where it also takes a less favourable course $[3,4]$. It is also interesting to note that the percentage of persons

\section{Einleitung}

\section{$\nabla$}

Man geht davon aus, dass auf viele Patientinnen mit chronischen Schmerzen die Diagnosekriterien der anhaltenden somatoformen Schmerzstörung (F 45.4) zutreffen, beim chronischen Unterbauchschmerz liegt die Quote etwa bei 60-80\% [1]. Die Definition der anhaltenden somatoformen Schmerzstörung nach ICD 10 lautet wie folgt: „Die vorherrschende Beschwerde ist ein andauernder, schwerer und quälender Schmerz, der durch einen physiologischen Prozess oder eine körperliche Störung nicht vollständig erklärt werden kann. Er tritt in Verbindung mit emotionalen Konflikten oder psychosozialen Belastungen auf, die schwerwiegend genug sein sollten, um als entscheidende ursächliche Faktoren gelten zu können. Die Folge ist meist eine beträchtlich gesteigerte persönliche oder medizinische Hilfe und Unterstützung. Schmerzzustände mit vermutlich psychogenem Ursprung, die im Verlauf depressiver Störungen oder einer Schizophrenie auftreten, sollten hier nicht berücksichtigt werden.“ [2]

Chronische Schmerzsyndrome können bei Patientinnen jeder Schicht und jedes Bildungsgrads auftreten. Sie kommen aber bei niedrigerem sozioökonomi- 
Table 1 Possible causes of and findings in chronic pelvic pain [1].

\begin{tabular}{|c|c|}
\hline & Causes and findngs \\
\hline $\begin{array}{l}\text { Gynaecologi- } \\
\text { cal disease }\end{array}$ & $\begin{array}{l}\text { - endometriosis/adenomyosis } \\
\text { - } \text { malignant gynaecological disease } \\
\text { - Pelvic Inflammatory Disease and its consequences (PID) } \\
\text { - Ovarian Retention syndrome/Ovarian Remnant } \\
\text { syndrome (Residual Ovary syndrome) } \\
\text { - adhesions } \\
\text { - leiomyomas } \\
\text { - cervical stenosis with haematometra } \\
\text { - dysmenorrhoea } \\
\text { - pain during ovulation } \\
\text { - malformations (e.g. accessory ovaries, duplex uterus) } \\
\text { Delvic venous stasis (pelvic varicosities) }\end{array}$ \\
\hline $\begin{array}{l}\text { Urological } \\
\text { disease }\end{array}$ & $\begin{array}{l}\text { - interstitial cystitis } \\
\text { - urethral syndrome } \\
\text { - malignant urological disease } \\
\text { - bladder dysfunction } \\
\text { - uronic inflammation of the urinary tract } \\
\text { - uroliasis }\end{array}$ \\
\hline $\begin{array}{l}\text { Gastrointes- } \\
\text { tinal disease }\end{array}$ & $\begin{array}{l}\text { - irritable bowel syndrome } \\
\text { - chronic constipation } \\
\text { - chronic inflammatory bowel disease } \\
\text { - malignant intestinal disease } \\
\text { - stenoses of the small or large intestine } \\
\text { - chronic intestinal pseudo-obstruction }\end{array}$ \\
\hline $\begin{array}{l}\text { Disease of the } \\
\text { musculoskele- } \\
\text { tal systems or } \\
\text { of the connec- } \\
\text { tive tissue }\end{array}$ & $\begin{array}{l}\text { - fibromyalgia } \\
\text { - myofascial paint, trigger points } \\
\text { - chronic back pain } \\
\text { - neuralgia/neuropathic pain syndrome } \\
\text { - Pelvic floor dysfunction } \\
\text { - cicatricial pain } \\
\text { - malignant disease of the musculoskeletal system } \\
\text { and of the connective tissue } \\
\text { - nerve compression syndrome } \\
\text { - hernias }\end{array}$ \\
\hline $\begin{array}{l}\text { Psychological } \\
\text { disorders }\end{array}$ & $\begin{array}{l}\text { - somatoform disorders } \\
\text { - adjustment disorders } \\
\text { - affective disorders } \\
\text { - schizophrenia, schizotypal disorders and delusions }\end{array}$ \\
\hline
\end{tabular}

not receiving care for chronic pain is $59.5 \%$, making it the second highest after addictive disorders [5].

- Table 1 lists various possible causes and findings for chronic pain syndrome, using persistent pelvic pain as an example.

\section{Fibromyalgia (FMS)}

Fibromyalgia or fibromyalgia syndrome (FMS) is defined as persistent pain in several areas of the body with painful response to pressure at 11 or more points out of 18 tender points. Other core symptoms include sleep disturbance and debilitating fatigue [6]. Although the aetiology of FMS is unknown, certain risk indicators have been identified which were found to be correlated with increased incidence. Frequently cited, precipitating, psychosocial factors include lifestyle factors such as smoking, obesity and a lack of physical activity, and psychological factors include physical and sexual abuse in childhood and adulthood, as well as increased stress at work [6]. It has been surmised that genetic factors also been play a role, with FMS occurring more frequently in certain families [7]. The current guidelines on FMS propose a biopsychosocial model for the pathogenesis of FMS: physical and/or biological and/or psychosocial stressors trigger vegetative and schem Status häufiger vor und nehmen dann auch eher einen ungünstigen Verlauf $[3,4]$. Interessant zu betrachten ist auch die Höhe der "Nicht-Versorgungsquote“ bei chronischen Schmerzsyndromen, sie liegt bei 59,5\% und damit am zweithöchsten nach den Suchterkrankungen [5].

In $\odot$ Tab. 1 sind die vielfältigen möglichen Ursachen und Befunde der chronischen Schmerzsyndrome am Beispiel des chronischen Unterbauchschmerzes dargestellt.

\section{Fibromyalgiesyndrom (FMS)}

Das FMS wird durch chronische Schmerzen in mehreren Körperregionen und Druckschmerzhaftigkeit von mindestens 11 von 18 Tender Points definiert. Weitere Kernsymptome sind Schlafstörungen und Müdigkeit bzw. Erschöpfungsneigung [6]. Zwar ist die Ätiologie des FMS ungeklärt, es lassen sich jedoch Risikoindikatoren identifizieren, die mit einer erhöhten Inzidenz korreliert sind. Es handelt sich dabei im psychosozialen Bereich um die vermehrte Angabe von Lebensstilfaktoren wie Rauchen, Übergewicht und mangelnde körperliche Aktivität sowie im psychischen Bereich um körperliche Misshandlung und sexuellen Missbrauch in Kindheit und Erwachsenenalter sowie Stress am Arbeitsplatz [6]. Außerdem werden genetische Faktoren vermutet, da das FMS familiär gehäuft vorkommt [7]. Die aktuelle Leitlinie zum FMS postuliert in der Pathogenese ein biopsychosoziales Modell: Physikalische und/oder biologische und/oder psychosoziale Stressoren lösen bei einer entsprechenden Prädisposition vegetative, endokrine und zentralnervöse Reaktionen aus, aus denen das FMS resultiert. Sowohl die Prädisposition als auch die vegetativen, endokrinen und zentralnervösen Reaktionen sind heterogen. Das FMS ist eine Endstrecke verschiedener ätiopathogenetischer Faktoren und pathophysiologischer Mechanismen.

Als pathophysiologische Mechanismen werden eine veränderte zentrale Schmerzverarbeitung, eine Dysfunktion der Hypothalamus-Hypophysen-Nebennieren-Achse sowie periphere Schmerzgeneratoren diskutiert [6]. Zumindest bei einer Subgruppe von FMS-Patienten liegt eine Schädigung des peripheren Nervensystems vor [8]. Es gibt keine Evidenz für einen Zusammenhang zwischen dem FMS und hormonellen Störungen oder kosmetischen Brustimplantaten, hierbei kann es sich jedoch um laienätiologische Vorstellungen handeln, die von den Patientinnen durchaus an den Gynäkologen herangetragen werden könnten [6]. Zu bedenken ist die Überlappung des FMS mit anhaltenden somatoformen Schmerzstörungen (F45.40) und der chronischen Schmerzstörung mit psychischen und somatischen Faktoren (F45.41).

Die Prävalenz wird auf 3,5\% geschätzt. Obwohl sich in epidemiologischen Studien das Geschlechterverhältnis bei FMS-Patienten nicht sehr unterscheidet, gilt das FMS als „Frauenkrankheit“ [8]. Es fällt jedoch auf, dass in klinischen Einrichtungen das Verhältnis Männer zu Frauen dagegen sehr unterschiedlich mit einem deutlich höheren Frauenanteil ist [9]. Dabei muss man berücksichtigen, dass Frauen generell bei chronischen körperlichen Beschwerden häufiger medizinische Leistungen in Anspruch nehmen als Männer [10].

Als Basisdiagnostik werden folgende Maßnahmen empfohlen:

- Ausfüllen einer Schmerzskizze oder der regionalen Schmerzskala durch den Patienten

- gezielte Exploration weiterer Kernsymptome (Müdigkeit, Schlafstörungen)

- vollständige medizinische Anamnese inkl. Medikamentenanamnese

- vollständige körperliche Untersuchung (inkl. Haut, neurologischer und orthopädischer Befund) 
endocrine reactions as well as reactions of the central nervous system in persons with a suitable predisposition, resulting in FMS. The predisposition, the vegetative and endocrine reactions, and the response of the central nervous system have a heterogeneous presentation. FMS is the final outcome of various aetiopathogenetic factors and pathophysiological mechanisms.

Possible pathophysiological mechanisms currently being discussed are changed central pain sensitization and dysfunction of the hypothalamic-pituitary-gonadal axis or of the peripheral pain generators [6]. At least in one subgroup of FMS patients, impairments to the peripheral nervous system were noted [8]. There is no evidence for an association between FMS and hormonal disorders or cosmetic breast implants; these suggested aetiologies are sometimes put to gynaecologists by "lay" women [6]. It is also important to remember the overlap between FMS and persistent somatoform pain disorders (F45.40) and chronic pain disorder with somatic and psychological factors (F45.41).

The incidence of FMS is estimated to be 3.5\%. Although the gender ratio for FMS patients does not differ much between genders in epidemiological studies, FMS is often considered a "female disorder" [8]. It is notable that the ratio between men and women who attend outpatient surgeries and clinics differs significantly, with a much higher percentage of women compared to men visiting a physician [9]. However, it should be noted that women in general are more likely to seek medical assistance for chronic physical complaints than men [10].

The following steps are suggested when making a basic diagnosis:

- Completion of a pain profile or a regional pain scale by the patient

- Targeted investigation of additional key symptoms (fatigue, sleep disorder)

- Complete medical history including history of medication

- Complete physical examination (incl. skin, neurological and orthopaedic findings)

This basic examination is necessary to exclude rheumatic disease (erythrocyte sedimentation rate, C-reactive protein, blood count, rheumatic parameters), myopathies (creatinine kinase), hypercalcaemia (calcium), and hypothyroidism (basal thyroid-stimulating hormone levels) [6].

If there is a suspicion that symptoms have (additional) somatic causes, this will affect subsequent diagnostic tests.

As the most common, psychological co-morbidities of FMS are depressive and anxiety disorders, screening for heightened psychological symptoms (anxiety and depression) is recommended. This can be done using the German version of the Patient Health Questionnaire PHQ-4 [11].

\section{Endometriosis}

$\nabla$

Endometriosis is a clinically relevant and important cause of chronic pelvic pain. It is one of the most common gynaecological medical conditions, although there are no reliable data regarding its incidence and prevalence in the literature. In Germany, around 40000 women are newly diagnosed with endometriosis annually. The long time ( 6 years on average) to diagnosis is problematic, as is the associated chronic course of the condition [12]. Hurd et al. proposed 3 criteria which would indicate that endometriosis was the cause of chronic pelvic pain: 1. pain occurs cyclically; 2. surgical confirmation; and 3. medication or surgical
Das Basislabor dient dem Ausschluss von rheumatischen Erkrankungen (Blutsenkungsgeschwindigkeit, C-reaktives Protein, kleines Blutbild, Rheumaparameter), Muskelerkrankungen (Kreatininkinase), Hyperkälzämie (Kalzium) und einer Hypothyreose (Thyreoidea-stimulierendes Hormon basal) [6].

Besteht der Verdacht auf somatische (Mit-)Ursachen der Symptomatik, ist die weitere Diagnostik davon abhängig.

Da die häufigsten komorbiden seelischen Störungen beim FMS depressive und Angststörungen sind, wird ein Screening auf vermehrte seelische Symptombelastung (Angst und Depression) empfohlen. Dies ist z.B. mit der deutschen Version des Patientenfragebogens zur Gesundheit PHQ-4 [11] möglich.

\section{Endometriose}

$\nabla$

Die Endometriose ist eine klinisch relevante und wichtige Ursache für chronischen Unterbauchschmerz. Sie gilt als eine der häufigsten gynäkologischen Erkrankungen, wobei verlässliche Angaben zur Inzidenz und Prävalenz in der Literatur fehlen. In Deutschland wird von etwa 40000 Neuerkrankungen pro Jahr ausgegangen. Problematisch sind auch das lange im Durchschnitt 6 Jahre betragende Intervall bis zur Diagnosestellung und der damit verbundene chronische Verlauf [12]. Hurd et al. postulierten 3 Kriterien, nach denen angenommen werden kann, dass ein chronischer, pelviner Schmerz durch Endometriose verursacht wird: 1 . der Schmerz tritt zyklisch auf, 2. es ist eine operative Bestätigung erfolgt und 3. durch eine medikamentöse und/ oder chirurgische Therapie wird eine anhaltende Besserung erzielt [13]. Fast jede Frau mit symptomatischer Endometriose leidet unter mehr oder weniger schwerer Dysmenorrhö. Wenn dieses Kardinalsymptom fehlt, sollten andere Differenzialdiagnosen des Unterbauchschmerzes bedacht werden [14]. Es gibt außerdem epidemiologische Untersuchungen, die auf eine Assoziation der Endometriose mit anderen chronischen Schmerzerkrankungen wie Migräne und chronischem Reizdarmsyndrom hinweisen [15-17, 22-24].

\section{Therapie chronischer Schmerzsyndrome in der Gynäkologie unter psychosomatischen Gesichtspunkten \\ $\nabla$}

Bei der Endometriose ist der Gynäkologe dafür prädestiniert, in der Therapie die Funktion des „Therapielotsen“ zu übernehmen. Meist besteht eine über Jahre gewachsene Arzt-Patientinnen-Beziehung, die eine gute Basis für die Therapiekoordination darstellt. Für das FMS gibt es diese Funktion nicht, sodass sich hier eher anbietet, dass die Behandlungskoordination in Händen eines Arztes liegt, der die notwendigen Kenntnisse und Erfahrungen zur Behandlung eines FMS hat $[6,25]$.

Auch wenn es dafür wenig wissenschaftliche Evidenz gibt, ist eine gelassene, empathische, aktiv-stützende, symptom- und bewältigungsorientierte Grundhaltung hilfreich, um zunächst eine tragfähige, partnerschaftliche Arbeitsbeziehung aufzubauen [10]. Die Arzt-Patientinnen-Beziehung wird vor allem bei schwereren Verläufen von beiden Seiten oft als schwierig erlebt, vonseiten des Behandelnden z.B. weil er seine Expertise infrage gestellt sieht, seitens der Patientin z.B. wegen verminderter Zufriedenheit mit der Behandlung. Eigene unangenehme Gefühle des Behandlers (Gegenübertragung) in Bezug auf die Patientin sowie eigene dysfunktionale Motive und Verhaltensmuster können aber kritisch reflektiert und ggf. therapeutisch genutzt werden. 
therapy results in longer term improvement [13]. Almost every woman with symptomatic endometriosis has more or less severe dysmenorrhoea. If this cardinal symptom is not present, other potential causes should be considered in the differential diagnosis of pelvic pain [14]. Some epidemiological investigations have suggested an association between endometriosis and other chronic pain disorders such as migraine and chronic irritable bowel syndrome [15-17,22-24].

\section{Psychosomatic Factors Affecting the Therapy of Chronic Pain Syndrome in Gynaecological Practice}

In the treatment of endometriosis, gynaecologists are predestined for the role of therapy "guide". Often the relationship between physician and patient has developed over several years, which offers a good basis for coordinating therapy. There is no such role for FMS, so the obvious course in this case would be to place the coordination of treatment in the hands of a physician with the necessary specialist knowledge and experience of treating FMS $[6,25]$.

Although there is not much scientific evidence for this, a calm, empathetic approach which offers active support and focuses on symptoms and on how to deal with them is helpful to create an initial stable working relationship [10]. The relationship between physician and patient is often experienced by both parties as difficult, particularly when the course of the disorder is unfavourable; the physician may feel that his expertise is being challenged, while the patient may be dissatisfied with the treatment she has received. In this case, the physician needs to critically reflect on his or her problematic feelings towards the patient (countertransference) and the dysfunctional motives and patterns of behaviour can be critically evaluated and possibly even used in therapy.

Typically, the following emotions may be triggered in the physician [10]:

- helplessness, uncertainty, perplexity, failure

- the feeling of first being idealised, then devalued,

- pressure to make decisions, feeling of having been deceived, wish to expose the other; feeling oneself under pressure

- power struggle, feeling of powerlessness, manipulation

- boredom, impatience, disappointment, anger, annoyance; frustration; rejection of the patient; wish to avoid the patient

- disappointment

\section{Therapeutic goals}

In gynaecological practice, the following main goals can be achieved:

- improvement of the patient's quality of life

- preventing the disorder from becoming chronic and the patient from harming herself, e.g. through extensive avoidance behaviour or iatrogenically through repeated diagnostics und risky therapies

- providing support if the pain has become chronic

- expanding the patient's explanatory model to include biopsychosocial factors and ways of coping

- motivating the patient to have psychotherapy with referral for specialised psychotherapy if the indications are present [10]

Examples of communicating therapeutic goals are given in - Table 2.

\begin{tabular}{|c|c|}
\hline $\begin{array}{l}\text { need to be decided } \\
\text { on together }\end{array}$ & $\begin{array}{l}\text { "Even if we have to assume that the complaint } \\
\text { will not disappear quickly or entirely, is there } \\
\text { something that could nevertheless increase the } \\
\text { quality of your life and make your life more worth } \\
\text { living?" } \\
\text { "What do you think could be an important result } \\
\text { of treatment for you?" }\end{array}$ \\
\hline need to be stepwise & $\begin{array}{l}\text { "You said that you used to be so optimistic: could } \\
\text { you imagine one of the goals being the improve- } \\
\text { ment and lightening of your mood? So that you } \\
\text { would be able to take up your hobby again?" }\end{array}$ \\
\hline $\begin{array}{l}\text { should seize on } \\
\text { pronounced anxiety } \\
\text { related to the } \\
\text { patient's health }\end{array}$ & $\begin{array}{l}\text { "Would it help if you no longer had to fear that } \\
\text { your complaint might have a serious underlying } \\
\text { cause?" }\end{array}$ \\
\hline
\end{tabular}

Typischerweise werden folgende Gefühle beim Behandler ausgelöst [10]:

- Hilflosigkeit, Unsicherheit, Ratlosigkeit, Scheitern

- Gefühl, erst idealisiert, dann entwertet zu werden

- Entscheidungsdruck, Getäuscht-Fühlen, Entlarven-Wollen; sich unter Druck gesetzt fühlen

- Machtkampf, Ohnmachtserleben, Manipulation

- Langeweile, Ungeduld, Enttäuschung, Wut, Ärger; Frustration; Ablehnung der Patientin; Wunsch, sich zu entziehen

- Enttäuschung

\section{Therapieziele}

Als Therapieziele kommen in der gynäkologischen Praxis vor allem folgende Punkte in Betracht:

- Verbesserung der Lebensqualität

- Verhinderung von Chronifizierung und Selbstschädigung, z.B. durch ausgeprägtes Schon- und Vermeidungsverhalten oder iatrogen durch repetitive Diagnostik und riskante Therapien

- Begleitung bei eingetretener Chronifizierung

- Erweiterung des Erklärungsmodells des Patienten hin zu einem biopsychosozialen Modell und seiner Bewältigungsmöglichkeiten

- Motivation und Überweisung zu einer Fachpsychotherapie bzw. fachbezogenen Psychotherapie, falls die Indikation hierfür gegeben ist [10]

Beispiele für die Kommunikation der Therapieziele sind in ๑ Tab. 2 aufgeführt.

Je eindeutiger kommuniziert wird, umso besser wird die Fähigkeit zur Selbststeuerung und damit die Selbstwirksamkeit der Patientinnen unterstützt [18] ( Tab. 3).

\section{Basistherapie}

$\nabla$

Der Versorgung in der gynäkologischen Praxis kommt eine besondere Bedeutung zu. Bereits in der Frühphase einer chronischen Schmerzerkrankung hilft ein angemessener Umgang, einen ungünstigen Verlauf durch iatrogene Faktoren zu verhindern [19]. Oft besteht auch der Wunsch der Patientin darin, von ihrem Gynäkologen behandelt zu werden und nicht weiter überwiesen zu werden [20]. Zur Anwendung gelangt in dieser Behandlungsphase vor allem die Psychosomatische Grundversorgung.

Als zentrales Therapiekonzept bei schweren Verläufen gilt die multimodale Schmerztherapie, sie erfordert eine interdisziplinäre Diagnostik durch mindestens 2 Fachdisziplinen (obligatorisch eine psy- 
Table 3 Examples of phrasing showing the physician's basic empathy [10].

\begin{tabular}{|c|c|}
\hline Communicate confidence & "At present there are no indications showing any serious physical underlying cause of your pain." \\
\hline Put high expectations and demands into perspective & $\begin{array}{l}\text { "In my experience, you should not tackle too much in one go. Let us move forward step by step } \\
\text { in many small steps." }\end{array}$ \\
\hline $\begin{array}{l}\text { Communicate openness with regard to diagnostic } \\
\text { and therapeutic decisions }\end{array}$ & $\begin{array}{l}\text { "We need to do this laparoscopic investigation because ..." } \\
\text { "I expect the findings to be unremarkable, that means..." }\end{array}$ \\
\hline $\begin{array}{l}\text { Do not focus only on medical topics but inquire } \\
\text { into psychosocial aspects }\end{array}$ & $\begin{array}{l}\text { "One aspect we should not lose sight of, in addition to the physical findings, is the question } \\
\text { of how you are managing to cope in your daily life with all the pain." }\end{array}$ \\
\hline $\begin{array}{l}\text { Inquire about psychosocial aspects which could be } \\
\text { relevant for the symptoms }\end{array}$ & $\begin{array}{l}\text { "Many of my patients with similar symptoms to yours have told me that these symptoms tended to } \\
\text { worsen when they were under stress or had a lot on their plate; would you say this is also true for you?" }\end{array}$ \\
\hline Do not lose sight of physical aspects & $\begin{array}{l}\text { "Recently we were able to identify some stressors in your life and you have started to focus } \\
\text { more on your own needs. How has the physical aspect of things progressed in the meantime?" }\end{array}$ \\
\hline $\begin{array}{l}\text { Do not attempt to deny the patient's real suffering; } \\
\text { instead, ask about the patient's subjective ideas } \\
\text { about her disease }\end{array}$ & $\begin{array}{l}\text { "I can see that you are really suffering with these stomach pains. I have heard that you have been } \\
\text { suffering for a long time. You have probably often thought about where your symptoms come from. } \\
\text { What are your conjectures?" }\end{array}$ \\
\hline $\begin{array}{l}\text { Do not accept the patient's own explanations } \\
\text { too quickly and uncritically }\end{array}$ & $\begin{array}{l}\text { "I can really understand why you came to that conclusion. But I think it is still too early to say } \\
\text { what the cause could be." } \\
\text { "In my experience, there is usually not a single cause; often several causes come together." }\end{array}$ \\
\hline $\begin{array}{l}\text { Show commitment and engagement } \\
\text { (and keep promises!) }\end{array}$ & $\begin{array}{l}\text { "I will be contacting my colleague to discuss your case." } \\
\text { "I will look into the options and find out more before our next appointment." }\end{array}$ \\
\hline $\begin{array}{l}\text { Do not give in to the impulse to take action } \\
\text { (too) quickly }\end{array}$ & $\begin{array}{l}\text { "Let us not jump the gun here." } \\
\text { "We need to take the time to monitor your progress over the next few weeks." }\end{array}$ \\
\hline
\end{tabular}

The clearer the communication, the more this will foster the patient's capacity to control processes herself and the patient's selfefficacy [18] ( Table 3).

\section{Primary Therapy}

First-line therapy is particularly important in gynaecological practice. Appropriate treatment in the early stage of a chronic pain syndrome can help prevent a subsequent unfavourable course due to iatrogenic factors [19]. Often patients prefer to be treated by their own gynaecologists and not referred to other physicians [20]. At this stage, treatment generally consists of psychosomatic primary care.

Multimodal pain therapy is a central therapy concept for disorders which take a severe course; it requires interdisciplinary diagnostics with the involvement of at least 2 medical specialties (it is mandatory that one of them is a psychiatric, psychosomatic or psychological specialty), and treatment includes the simultaneous use of at least 3 of the following active therapies under medical supervision: psychotherapy, special physiotherapy, relaxation training, ergotherapy, medical training therapy, sensorimotor training, workplace training, art or music therapy or other exercise therapies. Therapy must additionally include a review of the course of treatment using a standardised therapeutic assessment and discussion of the patient's progress by an interdisciplinary team [21].

Active listening techniques should be used in discussions with the patient (see 0 Table 4 ).

A review of the findings with the patient is pivotal as this discussion is held at a key time between diagnosis and therapy. When talking with patients, physicians should use language which is understood by the patient. The patient's complaints should be discussed and her experience validated through reconfirmation ("normalisation"), which may help calm the patient. Here again, it can be useful to take up metaphors used by the patient herself and to be aware of the "vicious circle" model for interpersonal communication of Friedemann Schulz von Thun and of stress chiatrische, psychosomatische oder psychologische Disziplin) und ist durch die gleichzeitige Anwendung von mindestens 3 der folgenden aktiven Therapieverfahren unter ärztlicher Behandlungsleitung definiert: Psychotherapie, spezielle Physiotherapie, Entspannungsverfahren, Ergotherapie, medizinische Trainingstherapie, sensomotorisches Training, Arbeitsplatztraining, Kunst- oder Musiktherapie oder sonstige übende Therapien. Sie umfasst weiter die Überprüfung des Behandlungsverlaufs durch ein standardisiertes therapeutisches Assessment mit interdisziplinärer Teambesprechung [21].

In der Gesprächsführung sollte das aktive Zuhören praktiziert werden (siehe ๑ Tab. 4).

Befundbesprechungen sind Schlüsselstellen am Übergang von Diagnostik zur Therapie. Sie sollten in verständlicher Sprache erfolgen. Die Beschwerden sollten im Sinne einer Rückversicherung („Normalisierung“) erklärt werden und die Patientin beruhigen. Auch hier ist es nützlich, Metaphern der Patientin aufzugreifen oder TeufelskreisModelle oder Modelle der Stressphysiologie einzusetzen. Nützlich kann auch der Hinweis sein, dass die Patientin mit ihren Beschwerden und Erfahrungen nicht alleine ist [10].

\section{Schwere Verläufe}

$\nabla$

Es gibt Indikatoren, die auf einen schwereren Verlauf hinweisen. Diese sind:

- mehrere Beschwerden

- häufige bzw. anhaltende Beschwerden (mit seltenen beschwerdefreien Intervallen)

- relevante psychosoziale Belastungsfaktoren, z.B. chronische Konflikte am Arbeitsplatz oder in der Familie

- relevante psychische Komorbidität, z. B. Depression, Angst, Sucht

- dysfunktionale Krankheitsannahmen, z.B. katastrophisierendes Denken, starke gesundheitsbezogene Ängste und dysfunktionale Verhaltensweisen, z.B. hohe Inanspruchnahme, Schon- und Vermeidungsverhalten

- starke funktionelle Beeinträchtigung, z.B. deutlich reduzierte Funktionsfähigkeit, Arbeitsunfähigkeit, sozialer Rückzug, körperliche Dekonditionierung

- Arzt-Patientin-Beziehung von beiden Seiten als „schwierig“ erlebt 
physiology models. Indicating to the patient that she is not alone with her complaints and experiences can also be useful [10].

\section{Serious Course}

There are some indications which suggest when a syndrome will take a serious course. Indicators include:

- the existence of several complaints

- frequent or persistent complaints (with rare pain-free intervals)

- relevant psychosocial stressors, e.g. chronic conflicts at work or in the family

- relevant psychological co-morbidities, e.g. depression, anxiety, addiction

- dysfunctional assumptions regarding the syndrome, e.g. catastrophising thinking, severe anxiety relating to health, and dysfunctional behaviour, e.g. high demands, avoidance behaviour

- severe functional impairment, e.g. significantly reduced functional capacity, incapacity for work, social withdrawal, physical deconditioning

- relationship between physician and patient considered "difficult" by both sides

Psychotherapeutic co-treatment is an important element of therapy when treating severe syndromes and should be initiated early on. In these cases it is useful to develop a good communication with other clinics, physicians and healthcare providers who have previously treated the patient or are currently treating her, not least to avoid multiple diagnoses and treatments. It is useful to build up and maintain a personal network with other caregivers treating the patient (specialist in internal medicine, neurologist/psychiatrist/psychologist, physiotherapist, psychotherapist, orthopaedist, etc.). Such a network will make it easier to coordinate and implement the joint patient care concept.

Psychotherapeutic treatment for FMS is recommended if the following combination of factors is present [6]:

- maladaptive coping strategies (e.g. catastrophising, inappropriate physical avoidance behaviour or dysfunctional coping mechanisms) and/or

- relevant impact on symptoms by everyday stressors and/or

- interpersonal problems and/or

- co-morbid psychological disorder

Recommended evidence-based methods include relaxation therapy and cognitive behavioural therapy combined with aerobic training as part of a multimodal concept. The data on all other types of psychotherapy is insufficient to be able to state whether they are effective or not [6]. It is not always easy to motivate a patient for psychotherapy, and motivation must be regarded as an important interim goal of treatment.

Medication for pain relief and to treat psychological complaints should only be given after the benefits and risks have been critically weighed up; medication should only be given for a limited period of time, and its use, i.e., the alleviation of symptoms, must be properly explained to the patient prior to prescribing the medication.

In every therapy, regular evaluation is important. If a therapy does not result in any subjective improvement of symptoms, it should be discontinued. For psychotherapeutic therapies we recommend a re-evaluation every 3 months [6].
Table 4 Examples of active listening [10].

\begin{tabular}{|c|c|}
\hline Summarising & $\begin{array}{l}\text { "I understand you to mean that..." } \\
\text { "I would summarise this as follows..." } \\
\text { "Did I understand you correctly that...?" } \\
\text { "If I try to imagine that for myself, } \\
\text { then this means that..." }\end{array}$ \\
\hline $\begin{array}{l}\text { Prefacing a change } \\
\text { of topic or interruption }\end{array}$ & $\begin{array}{l}\text { "Excuse me for interrupting you at this point..." } \\
\text { "Just a minute, there is something I would like } \\
\text { to ask..." } \\
\text { "Our time is almost up, therefore..." } \\
\text { "There is something I would still like to know..." }\end{array}$ \\
\hline $\begin{array}{l}\text { Signalling willingness } \\
\text { to work together }\end{array}$ & $\begin{array}{l}\text { "Do you find it difficult to talk about it?" } \\
\text { "Of course, it is not an easy topic to discuss." }\end{array}$ \\
\hline
\end{tabular}

Als wesentliches Therapieelement sollte bei schwereren Verläufen frühzeitig eine psychotherapeutische Mitbehandlung erfolgen. Besonders für diese Fälle ist es sinnvoll, eine gute Kooperation mit Vor-/Mitbehandlern und Kliniken aufzubauen, nicht zuletzt, um unnötige Mehrfachdiagnostik und -behandlung zu verhindern. Mit den häufig beteiligten Kooperationspartnern (Internist, Neurologe/Nervenarzt/Psychiater, Physiotherapeut, Psychotherapeut, Orthopäde etc.) sollte ein persönliches Netzwerk aufgebaut und gepflegt werden. Innerhalb dieser Netzwerke kann die Abstimmung eines gemeinsamen Versorgungskonzepts einfacher umgesetzt werden.

Eine psychotherapeutische Behandlung beim FMS wird bei folgenden klinischen Konstellationen empfohlen [6]:

- maladaptive Krankheitsbewältigung (z. B. Katastrophisieren, unangemessenes körperliches Vermeidungsverhalten bzw. dysfunktionale Durchhaltestrategien) und/oder

- relevante Modulation der Beschwerden durch Alltagsstress und/ oder

- interpersonelle Probleme und/oder

- komorbide psychische Störungen

Als evidenzbasierte Methoden werden Entspannungsverfahren sowie kognitive Verhaltenstherapie in Kombination mit aerobem Training im Rahmen eines multimodalen Konzepts empfohlen. Für alle anderen Psychotherapieformen gilt, dass die Datenlage nicht ausreichend ist, um diese als wirksam zu klassifizieren [6]. Die Motivation zur Psychotherapie ist nicht immer leicht zu erreichen und als wichtiges Zwischenziel im Behandlungsverlauf anzusehen.

Medikamente zur Schmerzlinderung und zur Behandlung psychischer Beschwerden sollten nach kritischer Nutzen-Risiko-Abwägung und nur dann eingesetzt werden, wenn die Einnahme zeitlich begrenzt ist und ihr Ziel, also die Symptomlinderung, der Patientin angemessen erklärt wird.

Bei jeder Therapie ist es wichtig, dass ihr Nutzen regelmäßig evaluiert wird. Bringt eine Therapie keine subjektive Verbesserung der Symptomatik, sollte sie nicht fortgeführt werden. Für psychotherapeutische Verfahren wird eine Evaluation alle 3 Monate empfohlen [6].

\section{Fazit für die Praxis}

$\nabla$

- Chronische Schmerzsyndrome sind häufig vorgetragene Beschwerdebilder in der gynäkologischen Praxis.

- Die Basistherapie sollte in der gynäkologischen Praxis angesiedelt sein und im Rahmen der psychosomatischen Grundversorgung stattfinden.

- Netzwerkbildung bei der Behandlung ist sinnvoll. 


\section{Conclusions}

$\nabla$

- Chronic pain syndrome is a common clinical picture in gynaecological practice.

- Primary therapy should start with the gynaecologist and must include basic psychosomatic care.

- Creation of a network of caregivers is useful to improve patient care.

\section{Conflict of Interest}

$\nabla$

None.

\section{References}

1 Deutsche Gesellschaft für Psychosomatische Frauenheilkunde und Geburtshilfe (DGPFG), Hrsg. Chronischer Unterbauchschmerz der Frau, S2-Leitlinie 2009. http://www.awmf.org/uploads/tx_szleitlinien/0160011.pdf; last access: 2.12.2012

2 ICD 10 (WHO): Internationale Klassifikation Psychischer Störungen. Kapitel F. 5. Aufl. Bern, Göttingen, Toronto, Seattle: Hans Huber Verlag; 2005

3 Latthe P, Mignini L, Gray R et al. Factors predisposing women to chronic pelvic pain: systematic review. BMJ 2006; 332: 749-755

4 Häuser W, Schmutzer G, Glaesmer H et al. Prävalenz und Prädiktoren von Schmerzen in mehreren Körperregionen. Ergebnisse einer repräsentativen deutschen Bevölkerungsstichprobe. Schmerz 2009; 23: 461-470

5 Wittchen HU, Jacobi F. Die Versorgungssituation psychischer Störungen in Deutschland. Eine klinisch-epidemiologische Abschätzung anhand des Bundes Gesundheitssurveys 1998. Bundesgesundheitsbl - Gesundheitsforsch - Gesundheitsschutz 2001; 44: 993-1000

6 Deutsche Interdisziplinäre Vereinigung für Schmerztherapie (DIVS), Hrsg. Definition, Pathophysiologie, Diagnostik und Therapie des Fibromyalgiesyndroms, S3-Leitlinie 2012. http://www.awmf.org/leitlinien/ detail/11/041-004.html; last access: 29.9.2012

7 Saxena A, Solitar BM. Fibromyalgia: knowns, unknowns, and current treatment. Bull NYU Hosp Jt Dis 2010; 68: 157-161

8 Caro XJ, Winter EF, Dumas AJ. A subset of fibromyalgia patients have findings suggestive of chronic inflammatory demyelinating polyneuropathy and appear to respond to IVIg. Rheumatology (Oxford) 2008; 47: 208-211

9 Häuser W, Kühn-Becker H, von Wilmoswky H et al. Demographic and clinical features of patients with fibromyalgia syndrome of different settings: a gender comparison. Gend Med 2011; 116-125

10 Hausteiner-Wiehle C, Schäfert R, Sattel H et al. (Steuerungsgruppe). S3Leitlinie zum Umgang mit Patienten mit nicht-spezifischen, funktionellen und somatoformen Körperbeschwerden 2012. http://www. awmf.org/leitlinien/detail/1//051-001.html; last access: 1.10.2012

11 Vlaeyen JW, Teeken-Gruben NJ, Goossens ME et al. Cognitive-educational treatment of fibromyalgia: a randomized clinical trial. I. Clinical effects. J Rheumatol 1996; 23: 1237-1245

12 Deutsche Gesellschaft für Gynäkologie und Geburtshilfe (DGGG); Deutsche Gesellschaft für Allgemein- und Viszeralchirurgie (DGAV), Hrsg. Diagnostik und Therapie der Endometriose. S1-Leitlinie 2010. http://www.awmf.org/leitlinien/detail/11/015-045.html; last access: 2.12.2012
Interessenkonflikt

Nein.
13 Hurd WW. Criteria that indicate endometriosis is the cause of chronic pelvic pain. Obstet Gynecol 1998; 92: 1029-1032

14 Sillem M, Teichmann AT. Patientinnenorientierte Aspekte der Endometriose. Gynäkologe 2003; 36: 41-52

15 Tietjen GE, Bushnell CD, Herial NA et al. Endometriosis is associated with prevalence of comorbid conditions in migraine. Headache 2007; 47: 1069-1078

16 Tietjen GE, Conway A, Utley C et al. Migraine is associated with menorrhagia and endometriosis. Headache 2006; 46: 422-428

17 Lea $R$, Bancroft $K$, Whorwell PJ. Irritable bowel syndrome, chronic pelvic inflammatory disease and endometriosis: a comparison of symptomatology. Eur J Gastroenterol Hepatol 2004; 16: 1269-1272

18 Foster NE, Thomas E, Bishop A et al. Distinctiveness of psychological obstacles to recovery in low back pain patients in primary care. Pain 2010; 148: 398-406

19 Reid S, Wessely S, Crayford T et al. Frequent attenders with medically unexplained symptoms: service use and costs in secondary care. $\mathrm{Br}$ J Psychiatry 2002; 180: 248-253

20 Kruse J, Schmitz N, Wöller W et al. [Why does the general practitioner overlook psychological disorders in his patient? Determinates of physicians' identification with psychological disorders.] Psychother Psychosom Med Psychol 2004; 54: 45-51

21 Arnold B, Häuser W, Bernateck M et al. Systematische Übersicht, Metaanalyse und Leitlinie: Multimodale Therapie des Fibromyalgiesyndroms. Schmerz 2012; 26: 287-290

22 Burghaus S, Klingsiek P, Fasching PA et al. Risk factors for endometriosis in a German case-control study. Geburtsh Frauenheilk 2011; 71: 1073-1079

23 Wölfler MM, Stadermann M, Rath W et al. Anamnestisches Screening bei symptomatischen Patientinnen mit und ohne Endometriose. Geburtsh Frauenheilk 2011; 71: 53-58

24 Breidenbach $M$, Schmidt T, Volkmer A et al. Identifikation geeigneter Zielstrukturen zur Entwicklung einer zielgerichteten Systemtherapie der Endometriose. Geburtsh Frauenheilk 2011; 71: 59-66

25 Reuter K. Psychoonkologie: Stellenwert, Prinzipien und Behandlungsansätze. Geburtsh Frauenheilk 2011; 71: R1-R16

Deutschsprachige Zusatzinformationen online abrufbar unter: www.thieme-connect.de/ejournals/toc/gebfra. 